\title{
The Teaching Method and Problems of Patient Information Handling in the Nursing Education Curriculum in Bachelor Course
}

Mikiko Natsume ${ }^{* 1}$ and Katusmasa OTA ${ }^{2}$

1Department of Nursing College of Life and Health Sciences, Chubu University, Japan

${ }^{2}$ Nagoya University Graduate School of Medicine Doctor of Medical Sciences, Japan.

"Corresponding author: Mikiko Natsume, Master of nursing, Department of Nursing College of Life and Health Sciences, Chubu University, 1200 Matsumotocho,Kasugai,aichi, 487-8501, Japan, Tel: 0568-51-1111; Fax: 0568-51-5370; E-mail:nmikiko@isc.chubu.ac.jp

Received date: October 02, 2014, Accepted date: November 28, 2014, Publication date: December 02, 2014

Copyright: ( 2014 Natsume M, et al. This is an open-access article distributed under the terms of the Creative Commons Attribution License, which permits unrestricted use, distribution, and reproduction in any medium, provided the original author and source are credited.

\begin{abstract}
Objective: The purpose of this paper is to describe the problems that arise in relation to nursing students' handling of patient information as well as the current status of students' instructions on the matter. The instructions needed to avoid these problems are also presented.

Methods: Research was conducted by giving self-report questionnaires to nursing faculty at Japanese nursing colleges as well as those directly instructing nursing practice.

Results: At present, these problems are not occurring by chance, but instead stem directly from students' low awareness of information privacy issues-suggesting that there is a need for more thorough instruction. Nursing faculty felt that the instruction they were already giving was effective for the most part in preventing most privacy problems. However, even instructions that a great number of nursing faculty members are implementing have been shown to be ineffective in some regards.At the same time, while detailed, time-consuming instruction and instruction that requires coordination with hospitals have been shown to be effective, there are few instructors who have experience carrying these out. In order to determine the appropriate features of instruction that would effectively prevent problems from occurring, a survey was again conducted on "necessary instruction". As a result, a diverse set of eighteen instruction items were identified, among them "emphasis on prohibited actions" and "implementation of review when problems occur".
\end{abstract}

Conclusion: The type of instruction deemed necessary is critical for the proper handling of patient information and includes basic content that can be applied outside of Japan as well.

Keywords: Patient information; Clinical practicum; Nursing education; Nursing teachers; Information privacy

\section{Introduction}

Privacy has been considered the "right to be left alone" however, nowadays the handling of personal information is not limited to the maintenance of confidentiality, but also includes the concept of "information privacy" [1], which includes ethical aspects related to the handling of information based on the Right to control of One's Own information. The HIPPA privacy rule [2] was enforced in the medical field in 1996, and official regulations when the patient information dealt with all medical institutions have been clarified.

The nursing student collects sensitive information of the patient in the clinical practice and records it and performs a nursing care. The literature reveals that in the course of this process, nursing students encounter a host of problems related to the handling of patient information, among them ethical issues related to privacy during information collection [3], problems with information sharing between students in academic settings [4], problems related to access to digital patient records, [5], and a lack of knowledge about patient information privacy. The American Association of Colleges of Nursing states that its baccalaureate program prepares the graduate to "uphold ethical standards related to data security, regulatory requirements, confidentiality, and clients' right to privacy" [6,7], suggesting that there is a need for education on protecting confidentiality when it comes to patient information. Hospitals must also deal with several confidentiality issues when it comes to patient information, including the sharing of that information among hospital staff $[8,9]$ and issues related to the security of patient information given the increasing use of information technology [10]. There is therefore a need for education that fosters the capabilities needed to handle this information appropriately within basic nursing clinical practice programs. In looking specifically at the kinds of students that should be the targets of this instruction, we find that many university websites post cautions and the like related to how patient information is to be treated. Still, although many countries have instructional guidelines designed to prevent the leakage of patient information through social media sites and similar channels [11,12], a search for other types of instruction did not reveal a single specific policy. Given this situation, this indicates that nursing faculty themselves are struggling as they provide students with instruction on patient information privacy and consider the results of that education from the students' point of view [13]. 
Citation: Natsume M, Katusmasa OTA (2014) The Teaching Method and Problems of Patient Information Handling in the Nursing Education

Page 2 of 10

\begin{tabular}{|l|l|l|l|}
\hline & Included & Not included & Don't know \\
\hline Caution regarding the location of the acquisition and handling of clients' personal information & $58(100.0)$ & $0(0.0)$ & $0(0.0)$ \\
\hline Explanation and consent of users related to handling of personal information & $53(91.4)$ & $5(8.6)$ & $0(0.0)$ \\
\hline Caution regarding accessing clients' personal information (in printed media/electronic media) & $53(91.4)$ & $3(5.2)$ & $2(3.4)$ \\
\hline Restrictions on copying clients' personal information (prohibition of photocopying, etc.) & $56(96.6)$ & $2(3.4)$ & $0(0.0)$ \\
\hline Ensuring anonymity of clients' personal information once acquired & $58(100.0)$ & $0(0.0)$ & $0(0.0)$ \\
\hline Preventing leakage of clients' personal information once acquired & $58(100.0)$ & $0(0.0)$ & $0(0.0)$ \\
\hline $\begin{array}{l}\text { Caution regarding restrictions on transportation of records related to practical nursing practice during nursing studies } \\
\text { (paper records, computers, storage media, etc.) (including data transfers), and storage locations }\end{array}$ & $55(94.8)$ & $3(5.2)$ & $0(0.0)$ \\
\hline $\begin{array}{l}\text { Methods of handling personal information during learning activities within the university, etc. (conferences, creating } \\
\text { papers/instructions) }\end{array}$ & $53(91.4)$ & $4(6.9)$ & $1(1.7)$ \\
\hline $\begin{array}{l}\text { Methods of storage and destruction of records related to practical nursing practice during nursing studies upon the } \\
\text { completion of nursing practice }\end{array}$ & $51(87.9)$ & $7(12.1)$ & $0(0.0)$ \\
\hline
\end{tabular}

Table 1: References in clinical practice guidelines to university rules in regard to the handling of patient information during clinical nursing practice $(n=58)$

\begin{tabular}{|c|c|c|c|}
\hline & Attribute & $\begin{array}{ll}\begin{array}{l}\text { Number } \\
\text { participants }\end{array} & \text { of }\end{array}$ & $\%$ \\
\hline \multirow{4}{*}{ Age } & $30 \mathrm{~s}$ & 28 & 21.2 \\
\hline & $40 \mathrm{~s}$ & 42 & 31.8 \\
\hline & over50 & 60 & 45.5 \\
\hline & NA & 2 & 1.5 \\
\hline \multirow{2}{*}{ Gender } & male & 14 & 10.6 \\
\hline & female & 118 & 89.4 \\
\hline \multirow{4}{*}{$\begin{array}{l}\text { Experience } \\
\text { teaching }\end{array}$} & under 5years & 16 & 12.1 \\
\hline & 5-10years & 42 & 31.8 \\
\hline & over10years & 73 & 55.3 \\
\hline & NA & 1 & 0.8 \\
\hline \multirow{6}{*}{ Position } & assistant & 3 & 2.3 \\
\hline & $\begin{array}{l}\text { research } \\
\text { associate }\end{array}$ & 31 & 23.5 \\
\hline & lecturer & 35 & 26.5 \\
\hline & $\begin{array}{l}\text { Associate } \\
\text { professor }\end{array}$ & 17 & 12.9 \\
\hline & professor & 45 & 34.1 \\
\hline & NA & 1 & 0.8 \\
\hline
\end{tabular}

Table 2: Background of respondents ( $\mathrm{n}=132)$.

If policies were in place regarding the content of instructions and methods for evaluation regarding the appropriate handling of patient information by student nurses, it is believed that it would be possible to include the requisite content in nursing practice. In order to achieve this, research was done in Japan with the aim of proposing necessary

instruction on patient information handling to be given to students undergoing on-site nursing practice -instruction on which consensus could be reached.

\section{Study purpose}

Identify the current status of instruction on nursing students' handling of patient information and associated problems. Propose the necessary instruction for preventing these problems from occurring.

\section{Methods}

\section{Data collection}

This study was comprised of the following two self-report questionnaires .

\section{(1) Regarding the provision or otherwise of regulations within the university related to the handling of patient information by student nurses}

The following survey was implemented in order to understand the existence or otherwise of regulations regarding consistent, instructions as a university on the handling of patient information.

Scope of survey:

Heads of nursing departments or nursing faculties at all nursing universities in Japan (217 in total) (hereinafter, referred to as "nursing department heads").

Survey method:

Self-report questionnaires. Surveys were distributed by mail, with responses collected by being directly mailed back.

\section{Contents of survey}

Nine categories directly related to the practice of students out of a total of 13 categories requiring consideration when guidelines are produced, according to "Hints for the creation of guidelines regarding 
the handling of personal information during nursing practice" [14] issued by the Japan Association of Nursing Programs in Universities, were selected and respondents were asked to comment on whether or not references to regulations related to university instructions were included within the clinical practice guidelines.

\section{(2) Problems experienced by individual members of nursing faculty and instructions to ensure that said problems do not occur}

In order to clarify the problems experienced by individual nursing faculty members along with what instructions has been experienced to ensure that said problems do not occur, the following survey was carried out among nursing faculty directly responsible for instructions.

\section{1) Subjects}

Nursing faculty directly responsible for practice instructions, with three or more years' experience providing clinical practice instructions. These subjects were selected because they are considered to have an understanding of the state of problems and instructions. In the current study, the objective was to extract problems occurring during practice in hospitals, etc., and consequently, nursing faculty working in areas of regional and home-based care were excluded.

\section{2) Survey procedure}

Nursing department heads at all nursing universities in Japan (217 in total) were requested to distribute survey documents, with those nursing department heads who cooperated asked to distribute documents to nursing faculty fulfilling the criteria. Responses were mailed back directly by the survey subjects.

\section{3) Survey method}

\section{(1) Selection procedure for survey items}

The survey items used in this survey were extracted after semistructured interviews with ten nursing faculty members directly responsible for clinical practice instructions, resulting in 24 problematic cases related to students' handling of patient information, along with 24 necessary instructions in order to prevent these problems from occurring. To these items were added aspects obtained from literary research, with any necessary instructions limited to those implemented by nursing faculty directly responsible for clinical practice. The results were organized into similar itemss by two researchers engaged in nursing practice studies, resulting in a total of 29 problematic cases, comprising "Caution regarding the location of the acquisition and handling of clients' personal information (4 cases)," "Ensuring anonymity of clients' personal information once acquired (5cases)," "Preventing leakage of clients' personal information once acquired (13cases)," "Caution regarding restrictions on transportation of records related to practical nursing practice during nursing studies and storage locations (1 case)," "Methods of handling personal information during learning activities within the university, etc. (conferences, creating papers/instructions) (4cases)," and "Methods of storage and destruction of records related to practical nursing practice during nursing studies upon the completion of nursing practice ( 2 cases)." Furthermore, in terms of any necessary instructions, a total of 27 survey instructions were extracted, covering "Thorough adherence to prohibitions (4instructions)," "Creating awareness of information privacy ( 3 instructions)," "Building systems to ensure management methods that do not cause problems (13instructions)," "Creation of management methods that minimize damage if a problem occurs (4instructions)" and "Reviewing behavior when problems occur (3 instructions)."

\section{(2) Response method}

Respondents were asked to select between three responses "experience frequently," "experience occasionally," "have never experienced" - in regard to their own experience during clinical practice instructions of the problematic cases, when student nurses handle patient information. Furthermore, they were asked whether or not they felt the problematic cases were in fact problems, using the responses "Think it is a problem," "Don't think it is a problem" and "Can't say." Furthermore, respondents were asked to provide details of any other problems they had experienced in their own words, along with whether or not they still consider them problems. In terms of any necessary instructions, they were asked whether they had experience with providing such instructions, using the two responses "Have experience" and "Have no experience," and nursing faculty with experience were further asked whether or not they felt it was effective, using the five responses "The problem stopped occurring," "The problem occurred less frequently," "The problem was made smaller," "There was no particular effect," and "Don't know." Furthermore, respondents were asked whether they considered instructions necessary, using the three responses "Consider it necessary," "Do not consider it necessary" and "Can't say."

4) Survey to confirm the instructions required to ensure that problems do not occur

In this survey, cooperating subjects were asked to comment on their experience with providing instructions, the effectiveness of instructions and the need for instructions in regard to instructions considered necessary, with the results used in order to implement a second survey on the need for instructions. While this paper does not propose specific guidelines, items deemed necessary by $51 \%$ or more of respondents were considered "necessary instruction items" in order to pinpoint potentially critical items.

\section{Data analysis}

The responses obtained were subjected to frequency analysis using SPSSVer18.0 as well as disparity verification (where $\mathrm{p} \leq 0.05$ ) based on the attributes of subjects (educational experience). The free answer areas were qualitatively compiled.

\section{Survey period}

The survey was conducted from November 2015 to February 2016.

\section{Ethical considerations}

When requesting permission to conduct the survey, the subjects received a written explanation of privacy protection and ethical considerations. The explanation included the maintenance of confidentiality of data collected, the fact that the data and contacts would not be used outside the purposes of the study, the maintenance of anonymity in terms both university surveys and unidentified surveys, and the fact that the contact details, names and other responses provided in order to facilitate repeat surveys would be separately stored in such a way that respondents could not be identified. Before beginning this research, we received approval from the Nagoya University School of Medicine Ethics Committee regarding the ethical considerations related to this research. 


\section{Results}

The survey results below address three key points with regards to whether universities issue written clinical practice guidelines or the like in order to regulate the handing of patient information throughout the institution: (1) Whether or not Clinical Nursing Practice Guidelines include reference to rule as university on the handling of patient information, (2) Problems that arise when nursing students handle patient information and the current status of instruction from nursing faculty, and (3) Necessary instruction to prevent problems. Hereinafter categories are marked "_," while cases and instructions are marked ' _.'

\section{Whether or not Clinical Nursing Practice Guidelines include reference to rule as university on the handling of patient information}

A total of 217 subjects were asked to cooperate with the survey, of which responses were received from 58 (response rate $26.7 \%$ ). The results are shown in Table 1 . These indicate that in all categories, $85 \%$ or more of universities make reference to university regulations in their clinical practice guidelines. Even in categories with lower numbers of universities making reference to regulations, $87.9 \%$ of respondents noted "Methods of storage and destruction of records related to practical nursing practice during nursing studies upon the completion of nursing practice".

\section{Problems that arise when nursing students handle patient information and the current status of instruction from nursing faculty}

Cooperation was obtained from 49 colleges, with 394 questionnaires distributed and 132 responses obtained (response rate $33.5 \%)$. Respondents' attributes are shown in Table 2. The majority of respondents were aged 50 or above $(45.5 \%)$, female $(89.4 \%)$, had 10 years or more teaching experience (55.3\%), and were professors $(34.1 \%)$.

\section{1) Problems related to the proper handling of patient information}

Table 3 indicates experience with potential problem items.

Nursing faculty reported 14 of the items have been experienced by at least $51 \%$, with $80 \%$ or more experiencing (1) the disclosure of information that could identify individuals, including actual names, at conferences with the practicum groups nursing practice (which falls under "methods of handling personal information during learning activities within the university, etc. (conferences, creating papers/ instructions)" and (2) the disclosure of highly sensitive personal information, including life history and lifestyle conditions, at conferences with the practicum group. Of the problematic case given, 25 were seen as problems by at least $51 \%$ of nursing faculty.

However, when nursing faculty were asked whether they thought these problematic cases were actually problems, many of them said that they included cases that they had experienced but did not consider problematic.

\section{2) Instructions given to prevent problems}

Responses related to experience in implementing instructions, its effectiveness and the necessity for such instructions when asked about instructions implemented to avoid problems are shown in Table 4. In terms of the effectiveness of instructions, "Instructions were effective" is considered indicated by the total number who responded "The problem stopped occurring," "The problem occurred less frequently" and "The problem was made smaller."

At least $51 \%$ of nursing faculty reported experience implementing 18 of the instruction items, and the majority felt that 15 of those items were effective. Although at least $51 \%$ of nursing faculty reported implementing the other three ('nursing faculty should demonstrate the appropriate handling of students' personal information in order to ensure students gain an awareness of the appropriate way to handle personal information', 'students are instructed to write their own name on all notes and nursing practice sheets', and 'if records of nursing practices or pamphlets for patient education are created using electronic media, students are instructed to take care in regard to the storage of media'), less than $51 \%$ felt they were effective.

In addition, there were seven items where less than $51 \%$ of nursing faculty reported implementing instruction, yet the majority felt that such instruction was effective. These included 'request that hospital staff demonstrate correct handling of patients' personal information (management of records, etc.) in order to ensure students gain an awareness of the appropriate way to handle personal information' and 'notebooks are coil-bound and covered with a white cover to prevent loss'.

\section{Necessary instruction to prevent problems}

There were 22 instruction items that least $51 \%$ of nursing faculty indicated as necessary to prevent problems.

Second survey was implemented among cooperating subjects to establish appropriateness in regard to instructions considered necessary in order to prevent problems from occurring. In this second survey, 45 questionnaires were distributed and 41 responses obtained (response rate 91.1\%). Instruction was deemed necessary for 18 items on the second survey. Table 5 shows the results. At least $51 \%$ of nursing faculty reported experience implementing instruction in 17 of the 18 items.

\section{Discussion}

\section{Current problems arising with nursing students handling patient information}

At least $51 \%$ of nursing faculty reported experience with 14 case items. These included not only accidents and situations where students were simply not careful, but a good number of incidents that occurred because students lacked proper awareness about how patient information had to be handled-such as 'records of nursing practice were created in a public place (on a train or in a restaurant, etc.' and 'actual name, profession, age, or other information making it possible to identify individuals was recorded on memos'. It has been said that this is a result of nursing faculty stressing these issues throughout the curriculum-not just during nursing practice, but during various lecturing and teaching opportunities as well [15]. It would seem that students need to be trained to handle patient information not only during nursing practice, but also need to be made aware of it during their academic courses, practice exercises, and the like.

Among the items that at least $51 \%$ of nursing faculty had experienced and at least $80 \%$ considered problems were 'records of 
nursing practice were forgotten or dropped (including those in electronic format)' and 'medical records or records of nursing practice were left open on a desk such that patient information was visible'which fall under the category of "preventing leakage of clients' personal information once acquired". Although issues like these are covered in the clinical practice guidelines and similar codes at all universities, the survey results indicate that there is a need for detailed and thorough instruction from nursing faculty to prevent them from occurring.

Of the items indicating potential issues with handling patient information, there were three that many (though less than $51 \%$ of) nursing faculty felt were in fact problems. Two of these were 'information that can identify individuals, including actual names, etc., was disclosed at conferences with the practicum group' and 'highly sensitive personal information, including life history and lifestyle conditions, was disclosed at conferences with the practicum group'both of which fall under "methods of handling personal information during learning activities within the university, etc. (conferences, creating papers/instructions)". Over $51 \%$ of nursing faculty had experienced these three items, indicating that students were sharing the information they had collected from patients as they participated in joint learning activities within their practicum groups. However, there are studies that show that patients themselves want their personal information shared only with the people directly involved in their lives [16], making it entirely possible that they would not agree to students not directly involved in their care having access to it. The National Student Nurses' Association writes, "in discussing client cases in the academic setting, care must be taken to avoid breeching confidentiality and violating HIPAA regulations; this includes appropriate selection of the time and place of discussion, people attending the discussion, and omitting data that is not necessary to the purpose of the discussion or that discloses the client's personal identity [17], which points to a need to creatively address the ways in which information on patients other than one's own is provided to others.

\section{Current instruction aimed at preventing problems}

It is clear that instruction being carried out on the university level in Japan today is based in regulations.
In addition, most of the nursing faculty who give this instruction feel that much of it is effective.

At the same time, at least $51 \%$ of nursing faculty surveyed said that although they issued instructions to the effect that (1) nursing faculty should demonstrate the appropriate handling of students' personal information in order to ensure students gain an awareness of the appropriate way to handle personal information, (2) students are instructed to write their own name on all notes and nursing practice sheets, and (3) if records of nursing practices or pamphlets for patient education are created using electronic media, students are instructed not to store them on their computers, less than half thought that these approaches were effective. It may be that awareness is low regarding the effectiveness of these instruction items because they are difficult to implement thoroughly and sufficiently communicate to students. However, it is most likely necessary to continue teaching them.

In the opposite category were seven instruction items that less than $51 \%$ of nursing faculty reported implementing, though a majority felt they were effective. Four of them (including 'notebooks are coil-bound and covered with a white cover to prevent loss', 'students are instructed to confirm the whereabouts of their records of nursing practice sheets at the beginning and end of each nursing practice session, based on a checklist', and 'nursing faculty check lockers and changing rooms to ensure that no records of nursing practices etc. have been left behind, after students go home') require tremendously detailed and time-consuming instruction, which is probably why this instruction is not being carried out. The other three, which included 'request that hospital staff demonstrate correct handling of patients' personal information (management of records, etc.) in order to ensure students gain an awareness of the appropriate way to handle personal information' and 'request that hospital staff not only provide nursing care, but also give instructions in the handling of patient information', require coordination with hospitals, suggesting that these instruction items are difficult to implement as well. Still, at least $51 \%$ of respondents indicated that these forms of instruction were needed (Table 3).

\begin{tabular}{|c|c|c|c|c|c|c|}
\hline & \multirow{2}{*}{ potentially problematic case } & \multicolumn{2}{|c|}{$\begin{array}{l}\text { Experience or otherwise regarding the } \\
\text { issue }\end{array}$} & \multicolumn{3}{|c|}{ Considered to be a problem or not? } \\
\hline & & Never & Experienced & $\begin{array}{l}\text { Dont consider it a } \\
\text { problem }\end{array}$ & $\begin{array}{l}\text { Consider it a } \\
\text { problem }\end{array}$ & $\begin{array}{l}\text { Cant say } \\
\text { either way }\end{array}$ \\
\hline \multirow{4}{*}{$\begin{array}{l}\text { Caution regarding the } \\
\text { location of the acquisition and } \\
\text { handling of clients personal } \\
\text { information }\end{array}$} & $\begin{array}{l}\text { Collection from patient or medical } \\
\text { records of information not required for } \\
\text { nursing purposes }\end{array}$ & 36.4 & 61.4 & 5.3 & 60.6 & 28 \\
\hline & $\begin{array}{l}\text { Viewing of information in medical } \\
\text { records related to patients other than } \\
\text { the student is treating }\end{array}$ & 69.7 & 28.8 & 10.6 & 65.2 & 18.9 \\
\hline & $\begin{array}{l}\text { The student communicates information } \\
\text { to a patient that he/she did not acquire } \\
\text { directly from the patient, but rather from } \\
\text { his/her medical records }\end{array}$ & 63.3 & 33.3 & 12.9 & 75 & 7.6 \\
\hline & $\begin{array}{l}\text { An ID or password used to browse } \\
\text { electronic medical records has been } \\
\text { shared between students }\end{array}$ & 75 & 22.7 & 9.8 & 68.2 & 17.4 \\
\hline
\end{tabular}


Citation: Natsume M, Katusmasa OTA (2014) The Teaching Method and Problems of Patient Information Handling in the Nursing Education

Page 6 of 10

\begin{tabular}{|c|c|c|c|c|c|c|}
\hline \multirow{5}{*}{$\begin{array}{l}\text { Ensuring anonymity of clients } \\
\text { personal information once } \\
\text { acquired }\end{array}$} & $\begin{array}{l}\text { Name of hospital and ward on which } \\
\text { practical nursing practice undertaken } \\
\text { was recorded in the records of nursing } \\
\text { practice }\end{array}$ & 30.3 & 67.5 & 18.9 & 65.9 & 10.6 \\
\hline & $\begin{array}{l}\text { Name of scheduled transfer hospital or } \\
\text { hospital to which transfer occurred was } \\
\text { recorded in the records of nursing } \\
\text { practice }\end{array}$ & 67.4 & 30.3 & 9.8 & 74.2 & 7.6 \\
\hline & $\begin{array}{l}\text { Actual age, profession or other } \\
\text { information making it possible to } \\
\text { identify individuals was recorded in the } \\
\text { records of nursing practice }\end{array}$ & 28 & 68.9 & 11.4 & 58.3 & 25 \\
\hline & $\begin{array}{l}\text { Actual name, profession, actual age, or } \\
\text { other information making it possible to } \\
\text { identify individuals was recorded on } \\
\text { memos }\end{array}$ & 0.8 & 74.3 & 7.6 & 68.2 & 16.7 \\
\hline & $\begin{array}{l}\text { Patient's initials were recorded in the } \\
\text { records of nursing practice }\end{array}$ & 28.8 & 67.4 & 15.2 & 59.1 & 20.5 \\
\hline \multirow{13}{*}{$\begin{array}{l}\text { Preventing leakage of clients } \\
\text { personal information once } \\
\text { acquired }\end{array}$} & $\begin{array}{l}\text { File used to store the records of } \\
\text { nursing practice was transparent, } \\
\text { allowing recorded contents to be seen } \\
\text { through the cover }\end{array}$ & 66.7 & 31 & 13.6 & 70.5 & 9.8 \\
\hline & $\begin{array}{l}\text { Records of nursing practice were } \\
\text { forgotten or dropped (including those in } \\
\text { electronic format) }\end{array}$ & 25 & 73.5 & 3.8 & 92.4 & 0 \\
\hline & $\begin{array}{l}\text { Records were stolen as a result of theft } \\
\text { from a parked car, etc }\end{array}$ & 91.7 & 6.8 & 8.3 & 83.3 & 1.5 \\
\hline & $\begin{array}{l}\text { A memo containing patient information } \\
\text { was dropped }\end{array}$ & 36.4 & 62.1 & 3 & 91.7 & 0 \\
\hline & $\begin{array}{l}\text { Original records of nursing practice } \\
\text { containing patient information were left } \\
\text { in the photocopier }\end{array}$ & 38.6 & 59.8 & 3.8 & 90.2 & 0 \\
\hline & $\begin{array}{l}\text { Medical records or records of nursing } \\
\text { practice were left open on a desk such } \\
\text { that patient information was visible }\end{array}$ & 37.1 & 60.6 & 6.1 & 84.8 & 5.3 \\
\hline & $\begin{array}{l}\text { Conversations regarding nursing } \\
\text { practice was held in a public place (on } \\
\text { a train, etc.) }\end{array}$ & 50 & 47.7 & 3 & 89.4 & 3.8 \\
\hline & $\begin{array}{l}\text { Records of nursing practice were } \\
\text { created in a public place (on a train or } \\
\text { in a restaurant, etc.) }\end{array}$ & 68.9 & 58.8 & 6.8 & 86.4 & 3.8 \\
\hline & $\begin{array}{l}\text { Student told his/her own family } \\
\text { information that the patient did not wish } \\
\text { to be known }\end{array}$ & 81.1 & 14.4 & 6.8 & 87.9 & 1.5 \\
\hline & $\begin{array}{l}\text { Information about nursing practice was } \\
\text { uploaded on a blog or social } \\
\text { networking service, etc. }\end{array}$ & 64.4 & 33.3 & 6.1 & 89.4 & 0.8 \\
\hline & $\begin{array}{l}\text { The patient's family was told } \\
\text { information that the patient him/herself } \\
\text { did not wish to be communicated }\end{array}$ & 92.4 & 5.3 & 6.8 & 81.1 & 5.3 \\
\hline & $\begin{array}{l}\text { A patient was told information about } \\
\text { another patient }\end{array}$ & 87.1 & 12.1 & 6.8 & 81.1 & 8.3 \\
\hline & $\begin{array}{l}\text { Patient information was communicated } \\
\text { to a visitor }\end{array}$ & 90.2 & 9.1 & 8.3 & 75.8 & 11.4 \\
\hline
\end{tabular}

Table 3: Experience or otherwise regarding the issues $(n=132 \%)$. 
Citation: Natsume M, Katusmasa OTA (2014) The Teaching Method and Problems of Patient Information Handling in the Nursing Education

Page 7 of 10

They require that nursing faculty maintain close communication and collaboration with the nurses who carry out nursing practice instruction at hospitals, which in turn suggests that nursing faculty must be the ones to reach out [18]. In short, nursing faculty must take the initiative to ensure that communication with nursing practice hospitals is robust enough to support the implementation of such instruction.

\section{Instructions agreed upon as necessary}

The first survey showed 22 items for which instruction was necessary in order to prevent problems from occurring, while consensus was reached about the necessity of all but four (18 items) in the second survey. Of the 18 items identified as necessary instructions, at least $51 \%$ of nursing faculty reported having experience with 17 of them. This leads us to determine that high-priority instruction items are also practical in terms of their ability to be taught. There was only one item for which there was consensus regarding their necessity but which were being implemented by less than $51 \%$ of nursing faculty, and it was 'Students are instructed that if records of nursing practices are created using electronic media, they should confirm deletion at the end of nursing practice'. Examples were found of American universities posting detailed warnings regarding digital records on their websites, such as "students must encrypt portable devices (e.g. laptops and USB drives, etc.) used to store patient or individual research data, and encrypt data files with Protected Health Information (PHI) if stored on a portable device that is not encrypted [19]. Although many nursing faculty feel that it is necessary for students to delete their digital records once their nursing practice is complete, it seems there is still a need for more specific, detailed instructions to this effect in cases were those digital records are being created.

The 18 necessary instruction items spanned all categoriesThorough adherence to prohibitions, Creating awareness of information privacy, Building systems to ensure management methods that do not cause problems, Creation of management methods that minimize damage if a problem occurs, and Reviewing behavior when problems occur-and indicate the need for diverse instructional approaches that address information privacy both before and after problems arise.

\begin{tabular}{|c|c|c|c|c|c|c|c|}
\hline & \multirow{3}{*}{\begin{tabular}{|l} 
Details of instructions \\
$\begin{array}{l}\text { Give an explanation, based on completed documents, of prohibited } \\
\text { actions in regard to handling patient information }\end{array}$
\end{tabular}} & \multicolumn{3}{|c|}{ Experience (\%) } & \multicolumn{3}{|c|}{ Need for instructions } \\
\hline & & \multicolumn{2}{|c|}{$\begin{array}{l}\text { Experience } \\
\text { (proportion who } \\
\text { said } \\
\text { instructions } \\
\text { were effective) }\end{array}$} & No experience & Required & Not required & Can't say \\
\hline \multirow{4}{*}{$\begin{array}{l}\text { Thorough } \\
\text { adherence to } \\
\text { prohibitions }\end{array}$} & & 92.4 & $(57.4)$ & 6.8 & 98.5 & 0.0 & 1.5 \\
\hline & $\begin{array}{l}\text { Give instructions, using practical examples, of specific cases of } \\
\text { handling patient information in which problems have arisen }\end{array}$ & 91.7 & $(65.3)$ & 8.3 & 97.0 & 0.8 & 2.3 \\
\hline & $\begin{array}{l}\text { Give instructions regarding prohibited actions in regard to handling } \\
\text { patient information, ensuring that the reasons can be understood }\end{array}$ & 92.4 & $(61.4)$ & 6.8 & 97.7 & 0.8 & 1.5 \\
\hline & $\begin{array}{l}\text { Give instructions regarding the fact that information regarding } \\
\text { nursing practice must not be disclosed on blogs or social } \\
\text { networking services }\end{array}$ & 81.8 & $(54.6)$ & 18.2 & 97.7 & 0.0 & 2.3 \\
\hline \multirow[t]{3}{*}{$\begin{array}{l}\text { Creating } \\
\text { awareness } \\
\text { information } \\
\text { privacy }\end{array}$} & $\begin{array}{l}\text { Request that hospital staff demonstrate correct handling of patients' } \\
\text { personal information (management of records, etc.) in order to } \\
\text { ensure students gain an awareness of the appropriate way to } \\
\text { handle personal information }\end{array}$ & 24.2 & $(75.0)$ & 74.2 & 60.6 & 7.6 & 31.1 \\
\hline & $\begin{array}{l}\text { Request that hospital staff not only provide nursing care, but also } \\
\text { give instructions in the handling of patient information }\end{array}$ & 37.9 & $(68.0)$ & 61.4 & 62.1 & 10.6 & 27.3 \\
\hline & $\begin{array}{l}\text { Nursing faculty should demonstrate the appropriate handling of } \\
\text { students' personal information in order to ensure students gain an } \\
\text { awareness of the appropriate way to handle personal information }\end{array}$ & 69.7 & $(46.8)$ & 28.0 & 81.1 & 1.5 & 16.7 \\
\hline \multirow{4}{*}{$\begin{array}{l}\text { Building systems } \\
\text { to } \quad \text { ensure } \\
\text { management } \\
\text { methods that do } \\
\text { not } \quad \text { cause } \\
\text { problems }\end{array}$} & $\begin{array}{l}\text { Students are instructed to use notebooks for note-taking that } \\
\text { cannot have single pages torn out of them }\end{array}$ & 90.2 & $(69.8)$ & 8.3 & 94.7 & 1.5 & 3.0 \\
\hline & $\begin{array}{l}\text { Notebooks are coil-bound and covered with a white cover to } \\
\text { prevent loss }\end{array}$ & 37.9 & $(80.0)$ & 59.8 & 43.9 & 12.1 & 43.9 \\
\hline & $\begin{array}{l}\text { Students are instructed to write their own name on all notes and } \\
\text { nursing practice sheets }\end{array}$ & 69.7 & $(50.0)$ & 28.0 & 68.9 & 12.9 & 18.2 \\
\hline & $\begin{array}{l}\text { Students are instructed to confirm the whereabouts of their records } \\
\text { of nursing practice sheets at the beginning and end of each nursing } \\
\text { practice session, based on a checklist }\end{array}$ & 22.0 & $(82.7)$ & 76.5 & 40.9 & 9.8 & 47.7 \\
\hline
\end{tabular}


Citation: Natsume M, Katusmasa OTA (2014) The Teaching Method and Problems of Patient Information Handling in the Nursing Education Curriculum in Bachelor Course. J Nurs Care 3: 219. doi:10.4172/2167-1168.1000219

Page 8 of 10

\begin{tabular}{|c|c|c|c|c|c|c|c|}
\hline & $\begin{array}{l}\text { Students are instructed to keep all records of nursing practice } \\
\text { sheets together in a file and keep the file in a paper bag, etc. }\end{array}$ & \begin{tabular}{|l}
90.2 \\
\end{tabular} & $(71.6)$ & 8.3 & 96.2 & 0.0 & 3.8 \\
\hline & $\begin{array}{l}\text { If records of nursing practices or pamphlets for patient education } \\
\text { are created using electronic media, students are instructed not to } \\
\text { store them on their computers }\end{array}$ & 58.3 & $(55.9)$ & 40.2 & 76.5 & 6.8 & 15.9 \\
\hline & $\begin{array}{l}\text { Notes and conference records are collected at the end of nursing } \\
\text { practice by nurse faculty }\end{array}$ & 53.0 & $(61.3)$ & 45.5 & 53.8 & 20.5 & 25.8 \\
\hline & $\begin{array}{l}\text { Students are instructed to record patients using numbers, which } \\
\text { cannot be traced to their names }\end{array}$ & 85.6 & $(69.0)$ & 13.6 & 88.6 & 3.0 & 7.6 \\
\hline & $\begin{array}{l}\text { Students are instructed to record "50s" or "60s" rather than the } \\
\text { actual age of patients }\end{array}$ & 68.9 & $(67.0)$ & 31.1 & 65.9 & 6.8 & 27.3 \\
\hline & $\begin{array}{l}\text { If records of nursing practices or pamphlets for patient education } \\
\text { are created using electronic media, students are instructed to take } \\
\text { care in regard to the storage of media }\end{array}$ & 70.5 & $(49.5)$ & 28.0 & 78.8 & 7.6 & 12.1 \\
\hline & $\begin{array}{l}\text { In conferences, etc., patient names are encoded to ensure that } \\
\text { identification is not possible before being published }\end{array}$ & 43.9 & $(65.6)$ & 53.8 & 41.7 & 31.8 & 25.8 \\
\hline & $\begin{array}{l}\text { Students are instructed that if records of nursing practices are } \\
\text { created using electronic media, they should confirm deletion at the } \\
\text { end of nursing practice }\end{array}$ & 47.7 & $(50.8)$ & 50.0 & 68.9 & 12.9 & 18.2 \\
\hline & $\begin{array}{l}\text { Nursing faculty check lockers and changing rooms to ensure that } \\
\text { no records of nursing practices etc. have been left behind, after } \\
\text { students go home }\end{array}$ & 28.8 & $(60.5)$ & 70.5 & 30.3 & 42.4 & 26.5 \\
\hline $\begin{array}{lr}\text { Creation } & \text { of } \\
\text { management } & \end{array}$ & $\begin{array}{l}\text { When copying records of nursing practices, students are instructed } \\
\text { to use photocopiers available only to hospital staff }\end{array}$ & 48.5 & $(70.3)$ & 47.0 & 59.1 & 15.9 & 22.7 \\
\hline $\begin{array}{ll}\text { minimize } & \text { damage } \\
\text { if } \quad \text { a } & \text { problem }\end{array}$ & $\begin{array}{l}\text { When copying records of nursing practices, students are instructed } \\
\text { to confirm in pairs that no original documents have been left behind }\end{array}$ & \begin{tabular}{|l|}
12.9 \\
\end{tabular} & $(21.2)$ & 82.6 & 38.6 & 22.0 & 35.6 \\
\hline & $\begin{array}{l}\text { Students are instructed not to record any information that enables } \\
\text { patient identification in notes }\end{array}$ & \begin{tabular}{|l}
90.2 \\
\end{tabular} & $(65.5)$ & 7.6 & 86.4 & 0.0 & 13.6 \\
\hline & $\begin{array}{l}\text { Students are instructed not to use clear-covered files to store } \\
\text { records }\end{array}$ & 61.4 & $(70.4)$ & 37.1 & 81.8 & 3.0 & 15.2 \\
\hline $\begin{array}{ll}\text { Reviewing } & \\
\text { behaviour when }\end{array}$ & $\begin{array}{l}\text { If records are left behind, etc., the student is contacted immediately } \\
\text { and made to understand the seriousness of his/her actions }\end{array}$ & 72.7 & $(71.9)$ & 26.5 & 99.2 & 0.0 & 0.8 \\
\hline & $\begin{array}{l}\text { If a problem occurs, a member of the nursing faculty works with the } \\
\text { student to review the cause, etc., and provide instructions }\end{array}$ & 75.0 & $(76.8)$ & 25.0 & 97.7 & 0.0 & 2.3 \\
\hline & $\begin{array}{l}\text { Every time a problem occurs, students are cautioned and given } \\
\text { instructions to ensure that he/she learns the correct behavior }\end{array}$ & 81.8 & $(68.5)$ & 17.4 & 98.5 & 0.8 & 0.8 \\
\hline
\end{tabular}

Table 4: Experience in regard to instructions, its effectiveness $n=132 \%$.

${ }^{*}$ In terms of the effectiveness of instructions, "Instructions were effective" is the total number who responded "The problem stopped occurring," "The problem occurred less frequently" and "The problem was made smaller."

\begin{tabular}{|l|l|l|l|l|}
\hline & & \multicolumn{3}{|l|}{ need for instruction $(\mathrm{n}=41) \%$} \\
\hline & Details of instructions & Required & $\begin{array}{l}\text { Not } \\
\text { require } \\
\mathrm{d}\end{array}$ & Can't say \\
\hline $\begin{array}{l}\text { Thorough } \\
\text { adherence } \\
\text { to } \\
\text { prohibitions }\end{array}$ & $\begin{array}{l}\text { Give an explanation, } \\
\text { based on rompleted } \\
\text { documents, of prohibited } \\
\text { actions in regard to } \\
\text { handling patient } \\
\text { information }\end{array}$ & & 0 & 0 \\
\hline
\end{tabular}

\begin{tabular}{|l|l|l|l|l|}
\hline & $\begin{array}{l}\text { Give instructions, using } \\
\text { practical examples, of } \\
\text { specific cases of handling } \\
\text { patient information in } \\
\text { which problems have } \\
\text { arisen }\end{array}$ & 000 & 0 \\
\hline $\begin{array}{l}\text { Give instructions regarding } \\
\text { prohibited actions in } \\
\text { regard to handling patient } \\
\text { information, ensuring that } \\
\text { the reasons can be } \\
\text { understood }\end{array}$ & 100 & 0 & 0 \\
\hline $\begin{array}{l}\text { Give instructions regarding } \\
\text { the fact that information } \\
\text { regarding nursing practice } \\
\text { must not be disclosed on }\end{array}$ & 100 & 0 & 0 \\
\hline
\end{tabular}


Citation: Natsume M, Katusmasa OTA (2014) The Teaching Method and Problems of Patient Information Handling in the Nursing Education

Page 9 of 10

\begin{tabular}{|c|c|c|c|c|}
\hline & $\begin{array}{l}\text { blogs or social networking } \\
\text { services }\end{array}$ & & & \\
\hline \multirow[t]{3}{*}{$\begin{array}{l}\text { Creating } \\
\text { awareness } \\
\text { of } \\
\text { information } \\
\text { privacy }\end{array}$} & $\begin{array}{l}\text { Request that hospital staff } \\
\text { demonstrate correct } \\
\text { handling of patients' } \\
\text { personal information } \\
\text { (management of records, } \\
\text { etc.) in order to ensure } \\
\text { students gain an } \\
\text { awareness of the } \\
\text { appropriate way to handle } \\
\text { personal information }\end{array}$ & 46.3 & 19.5 & 34.1 \\
\hline & $\begin{array}{l}\text { Request that hospital staff } \\
\text { not only provide nursing } \\
\text { care, but also give } \\
\text { instructions in the handling } \\
\text { of patient information }\end{array}$ & 48.8 & 29.3 & 22 \\
\hline & $\begin{array}{l}\text { Nursing faculty should } \\
\text { demonstrate the } \\
\text { appropriate handling of } \\
\text { students' personal } \\
\text { information in order to } \\
\text { ensure students gain an } \\
\text { awareness of the } \\
\text { appropriate way to handle } \\
\text { personal information }\end{array}$ & 75.6 & 17.1 & 7.3 \\
\hline \multirow{8}{*}{$\begin{array}{l}\text { Building } \\
\text { systems to } \\
\text { ensure } \\
\text { managemen } \\
\mathrm{t} \text { methods } \\
\text { that do not } \\
\text { cause } \\
\text { problems }\end{array}$} & $\begin{array}{l}\text { Students are instructed to } \\
\text { use notebooks for note- } \\
\text { taking that cannot have } \\
\text { single pages torn out of } \\
\text { them }\end{array}$ & 92.7 & 0 & 7.3 \\
\hline & $\begin{array}{l}\text { Notebooks are coil-bound } \\
\text { and covered with a white } \\
\text { cover to prevent loss }\end{array}$ & 24.4 & 24.4 & 51.2 \\
\hline & $\begin{array}{l}\text { Students are instructed to } \\
\text { write their own name on all } \\
\text { notes and nursing practice } \\
\text { sheets }\end{array}$ & 68.3 & 9.8 & 22 \\
\hline & $\begin{array}{l}\text { Students are instructed to } \\
\text { confirm the whereabouts } \\
\text { of their records of nursing } \\
\text { practice sheets at the } \\
\text { beginning and end of each } \\
\text { nursing practice session, } \\
\text { based on a checklist }\end{array}$ & 14.6 & 34.1 & 48.8 \\
\hline & $\begin{array}{l}\text { Students are instructed to } \\
\text { keep all records of nursing } \\
\text { practice sheets together in } \\
\text { a file and keep the file in a } \\
\text { paper bag, etc. }\end{array}$ & 100 & 0 & 0 \\
\hline & $\begin{array}{l}\text { If records of nursing } \\
\text { practices or pamphlets for } \\
\text { patient education are } \\
\text { created using electronic } \\
\text { media, students are } \\
\text { instructed not to store } \\
\text { them on their computers }\end{array}$ & 73.2 & 4.9 & 22 \\
\hline & $\begin{array}{l}\text { Notes and conference } \\
\text { records are collected at } \\
\text { the end of nursing practice } \\
\text { by nurse faculty }\end{array}$ & 34.1 & 26.8 & 39 \\
\hline & $\begin{array}{l}\text { Students are instructed to } \\
\text { record patients using } \\
\text { numbers, which cannot be } \\
\text { traced to their names }\end{array}$ & 95.1 & 0 & 4.9 \\
\hline
\end{tabular}

\begin{tabular}{|c|c|c|c|c|}
\hline & $\begin{array}{l}\text { Students are instructed to } \\
\text { record " } 50 \text { s" or " } 60 \text { s" rather } \\
\text { than the actual age of } \\
\text { patients }\end{array}$ & 65.9 & 12.2 & 22 \\
\hline & $\begin{array}{l}\text { If records of nursing } \\
\text { practices or pamphlets for } \\
\text { patient education are } \\
\text { created using electronic } \\
\text { media, students are } \\
\text { instructed to take care in } \\
\text { regard to the storage of } \\
\text { media }\end{array}$ & 85.4 & 2.4 & 12.2 \\
\hline & $\begin{array}{l}\text { In conferences, etc., } \\
\text { patient names are } \\
\text { encoded to ensure that } \\
\text { identification is not } \\
\text { possible before being } \\
\text { published }\end{array}$ & 22 & 41.5 & 36.6 \\
\hline & $\begin{array}{l}\text { Students are instructed } \\
\text { that if records of nursing } \\
\text { practices are created using } \\
\text { electronic media, they } \\
\text { should confirm deletion at } \\
\text { the end of nursing practice }\end{array}$ & 78 & 2.4 & 19.5 \\
\hline & $\begin{array}{l}\text { Nursing faculty check } \\
\text { lockers and changing } \\
\text { rooms to ensure that no } \\
\text { records of nursing } \\
\text { practices etc. have been } \\
\text { left behind, after students } \\
\text { go home }\end{array}$ & 14.6 & 48.8 & 36.6 \\
\hline \multirow{4}{*}{$\begin{array}{l}\text { Creation of } \\
\text { managemen } \\
t \quad \text { methods } \\
\text { that } \\
\text { minimize } \\
\text { damage if a } \\
\text { problem } \\
\text { occurs }\end{array}$} & $\begin{array}{l}\text { When copying records of } \\
\text { nursing practices, students } \\
\text { are instructed to use } \\
\text { photocopiers available } \\
\text { only to hospital staff }\end{array}$ & 31.7 & 17.1 & 43.9 \\
\hline & $\begin{array}{l}\text { When copying records of } \\
\text { nursing practices, students } \\
\text { are instructed to confirm in } \\
\text { pairs that no original } \\
\text { documents have been left } \\
\text { behind }\end{array}$ & 17.1 & 19.5 & 56.1 \\
\hline & $\begin{array}{l}\text { Students are instructed not } \\
\text { to record any information } \\
\text { that enables patient } \\
\text { identification in notes }\end{array}$ & 97.6 & 0 & 2.4 \\
\hline & $\begin{array}{l}\text { Students are instructed not } \\
\text { to use clear-covered files } \\
\text { to store records }\end{array}$ & 82.9 & 4.9 & 12.2 \\
\hline \multirow[t]{3}{*}{$\begin{array}{l}\text { Reviewing } \\
\text { behaviour } \\
\text { when } \\
\text { problems } \\
\text { occur }\end{array}$} & $\begin{array}{l}\text { If records are left behind, } \\
\text { etc., the student is } \\
\text { contacted immediately and } \\
\text { made to understand the } \\
\text { seriousness of his/her } \\
\text { actions }\end{array}$ & 97.6 & 0 & 2.4 \\
\hline & $\begin{array}{l}\text { If a problem occurs, a } \\
\text { member of the nursing } \\
\text { faculty works with the } \\
\text { student to review the } \\
\text { cause, etc., and provide } \\
\text { instructions }\end{array}$ & 92.7 & 0 & 7.3 \\
\hline & $\begin{array}{l}\text { Every time a problem } \\
\text { occurs, students are } \\
\text { cautioned and given } \\
\text { instructions to ensure that }\end{array}$ & 95.1 & 2.4 & 2.4 \\
\hline
\end{tabular}


Citation: Natsume M, Katusmasa OTA (2014) The Teaching Method and Problems of Patient Information Handling in the Nursing Education Curriculum in Bachelor Course. J Nurs Care 3: 219. doi:10.4172/2167-1168.1000219

Page 10 of 10

\begin{tabular}{|l|l|l|l|l|}
\hline & $\begin{array}{l}\text { he/she learns the correct } \\
\text { behavior }\end{array}$ & & & \\
\hline
\end{tabular}

Table 5: Need for instructions (second survey)\%.

\section{Conclusion}

As a result of this survey, it has become clear that when student nurses handle patient information during clinical practice, a range of problems occur in areas including "Preventing leakage of clients' personal information once acquired" and "Ensuring anonymity of clients' personal information once acquired" Moreover, in order to prevent these problems, a total of 18 instructions of required instructions were extracted, ranging from "Thorough adherence to prohibitions" through to "Reviewing behavior when problems occur."

\section{Limitation}

As a result of this study, problems occurring when student nurses handle information, along with the instructions required to prevent them from happening, were comprehensively studied. As the scope of the study was limited, however, it is not possible to state that its results cover all the required instructions. Furthermore, multiple factors contribute to the effectiveness of instructions, making it difficult to focus on a single factor when discussing effectiveness.

Nursing practice at nursing colleges takes many forms in different countries, and cannot be treated as a general category. At the same time, information privacy concepts are specified in the eight OECD Privacy Principles [20], which surely include content that can be incorporated into instructions given in any country.

\section{Acknowledgement}

The authors would like to thank all the department heads and nursing faculty at the nursing universities cooperating with this survey.

\section{References}

1. Bélanger F, Crossler R.E (2011)Privacy in the digital age: a review of information privacy researchin information systems, MIS Quarterly 35: 1017-1041.

2. U.S. Department of Health \& Human Services (1996) Health Information Privacy

3. Reis Pessalacia, Juliana Dias, Tavares et al (2013) Perception of nursing students about behaviors and ethical aspects involved in patient data collectionInvestigation and Education 31:210-217.
4. MatlakalaMC,MokoenaJD (2011) Student nurse's views regarding disclosure of patient's confidential information, South Africa family Practice 53:481-487.

5. Luke Davis, Jennifer. A. Domm, Michel.R Konikoff (1999) Attitudes of First-year Medical Students toward the Confidentiality of Computerized Patient Records, Journal of American informatics Association 6:55-60.

6. Kapborg ID, Berterö CM (2009)Swedish student nurses' knowledge of health statutes: a descriptive survey, International nursing review 56 : 222-229.

7. American association of college of nursing (2008)The Essentials of Baccalaureate Education for Professional Nursing Practice:19

8. Claire McGowan(2012)Patient's Confidentiality, Clinical care nurse 32:61-65

9. Nahid Dehghan Nayeri, Mohammad Aghajani(2010) Patients' privacy and satisfaction in the emergency department: A descriptive analytical study. Nursing ethics 17:167-177

10. Elizabeth J (2008) Ethical Issues and electronic health records. The Health Care Manager 2:165-176.

11. National Student Nurses Association. (n.d.) Recommendations for: Social media usage and maintaining privacy, confidentiality and professionalism.

12. Royal College of Nursing (2009) Legal advice for RCN members using the internet.

13. Mikiko NATSUME, KatsumasaOTA (2013)Problems in nursing students' handling of patient information in clinical practicums, and instruction methods to prevent them, Japanese Journal of Nursing and Health Sciences11:1-9. (in Japanese)

14. Japan Association of Nursing Programs in Universities (2005) For the purpose of creating guidelines regarding the handling of personal information during practical clinical practice in nursing. in Japanese

15. Paige W, Isakson J, Walden D (2005) HIPPA and Nursing EducationHow to Teach in a paranoid Health Care Environment, Journal of Nursing Education 44:489-492.

16. Katsumasa OTA (2007) Study on Information Sharing of Patient's Information in Nursing considering Information Privacy 2003-2005. Grant-in-Aid for Scientific Research(C) Results of research report.

17. National students nurse association (2009) Code of Ethics: Part IICode of Academic and Clinical Conductand Interpretive Statements (in Japanese).

18. Satoko YAMADA, Katsumasa OTA(2012) Essentialroles of clinical nurse instructors in Japan: A Delphi study. Nursing and HealthSciences 14:229-237

19. Columbia university, Confidentiality, Electronic Media,\& Protected Patient Information

20. OECD (2013) Flows of Personal Data Guidelines on the Protection of Privacy and Transborder Flows of Personal Data. 